\title{
1 A high content microscopy screening identifies new genes involved in cell width control 2 in Bacillus subtilis
}

3

4 Dimitri Juillot ${ }^{\mathrm{a}}$, Charlène Cornilleau ${ }^{\mathrm{a}}$, Nathalie Deboosere ${ }^{\mathrm{b}}$, Cyrille Billaudeau $^{\mathrm{a}}$, Parfait Evouna-Mengue ${ }^{\mathrm{c}}$,

5 Véronique Lejard ${ }^{\mathrm{c}}$, Priscille Brodin ${ }^{\mathrm{b}}$, Rut Carballido-López ${ }^{\mathrm{a}, \mathrm{t}}$ and Arnaud Chastanet ${ }^{\mathrm{a}, \#}$.

6

7

$8 \quad{ }^{a}$ Micalis Institute, INRAE, AgroParisTech, Université Paris-Saclay, 78350 Jouy-en-Josas, France.

$9{ }^{\mathrm{b}}$ Univ. Lille, CNRS, INSERM, CHU Lille, Institut Pasteur de Lille, CIIL-Center for Infection and Immunity of 10 Lille-U1019-UMR 9017; US41-UMS2014- PLBS, F-59000 Lille, France

${ }^{\mathrm{c}}$ Université Paris-Saclay, INRAE, MetaGenoPolis, 78350, Jouy-en-Josas, France

\#Corresponding authors: rut.carballido-lopez@inrae.fr, arnaud.chastanet@inrae.fr

Running title: Genome-wide screen reveals width determinants in B. subtilis

Keywords: Cell growth, cell shape, cell width, HCS microscopy, Bacillus subtilis, Min system, Rod complex, cell division, metabolism 


\section{Abstract}

27 How cells control their shape and size is a fundamental question of biology. In most bacteria, cell shape is imposed by the peptidoglycan (PG) polymeric meshwork that surrounds the cell. Thus, bacterial cell morphogenesis results from the coordinated action of the proteins assembling and degrading the PG shell. Remarkably, during steady-state growth, most bacteria maintain a defined shape along generations, suggesting that error-proof mechanisms tightly control the process. In the rod-shaped model for Gram-positive bacteria Bacillus subtilis, the average cell length varies as a function of the growth rate but the cell diameter remains constant throughout the cell cycle and across growth conditions. Here, in an attempt to shed light on the cellular circuits controlling bacterial cell width, we developed a screen to identify genetic determinants of cell width in B. subtilis. Using high-content screening (HCS) fluorescence microscopy and semi-automated measurement of single-cell dimensions, we screened a library of $\sim 4000$ single knockout mutants. We identified 13 mutations significantly altering cell diameter, in genes that belong to several functional groups. In particular, our results indicate that metabolism plays a major role in cell width control in B. subtilis. 


\section{Introduction:}

The bacterial landscape displays a rich variety of cell shapes, which are usually highly conserved at the single bacterial species level (1). The rationale behind a specific shape and its selective value remains speculative in most cases (1), as well as the molecular mechanisms that enable a specific shape to be determined and maintained across generations.

The shape of most bacterial cells directly depends on the shape of their cell wall (CW). The $\mathrm{CW}$ is primarily composed of a peptidoglycan (PG) scaffold that forms a rigid shell responsible for the mechanical properties of the cell envelope. In Gram-positive $(\mathrm{G}(+))$ bacteria, the $\mathrm{CW}$ additionally contains PG-linked glycopolymers, the most abundant being the teichoic acids (TAs) (2). The PG sacculus is a contiguous matrix of linear sugar strands cross-linked by peptide bridges (3). Rod-shaped bacteria like Bacillus subtilis and Escherichia coli, the models for $\mathrm{G}(+)$ and Gram-negative (G(-)) bacteria respectively, use two different PG-synthesizing machineries: the divisome and the elongasome $(4,5)$. The divisome is required to build the septum at the sites of division, which upon cell separation will become the new polar caps of the resulting daughter cells. The elongasome synthesizes the cylindrical sidewall during cell elongation. The latter comprises two machineries working semi-independently: one involving aPBPs (class A penicillin binding proteins), bifunctional enzymes with transpeptidase (TP) and transglycosylase (TG) activity, and one named the "Rod complex", which contains the SEDS-family RodA TG acting in concert with bPBPs (class B PBPs) carrying mono-functional TP activity such as $\mathrm{PBP} 2 \mathrm{~A}$ and $\mathrm{PbpH}$ in $B$. subtilis $(5,6)$. The prevailing model postulates that the Rod complex processively and directionally inserts glycan strands around the cell circumference, building the bulk of the PG meshwork, while aPBPs perform limited and localized, unoriented strands insertion (6-8). In agreement with this model, in B. subtilis aPBPs are dispensable (9-11) while most PG synthases of the Rod complex are essential, like RodA $(6,9,12)$, or co-essential like PBP2A and $\mathrm{PbpH}$ (13). This essentiality reflects that a failure in the proper establishment of the PG mesh compromises cellular integrity.

In addition to TP and TG enzymes, the Rod complex also includes the essential MreC and MreD morphogenetic proteins, which are presumed regulators of the activity of the complex $(4,14)$, and 
actin-like MreB proteins, which are believed to orient the circumferential motion of the complex (5, 15). The B. subtilis genome encodes three MreB paralogs, the essential MreB and Mbl, and MreBH, which becomes essential in the absence of the other two paralogs, in the absence of aPBPs, under stress conditions and at low $\mathrm{Mg}^{2+}$ concentrations $(11,16,17)$. RodZ, a protein of unknown function, is also a component of the Rod complex shown to be critical for rod shape maintenance in the G(-) bacteria Caulobacter crescentus and E. coli, and essential only in C. crescentus (18-21). The involvement of RodZ in shape control and its essentiality are less clearly established in $\mathrm{G}(+)$ bacteria. Described as essential in B. subtilis in an early report (22), several rodZ insertional or deletion mutants have been reported since, displaying minimal shape defects (23-25).

It has long been known that rod-shaped bacteria vary their size depending on the growth conditions and in particular on nutrient availability $(26,27)$. Rapidly growing cells have a bigger volume that slowly growing cells, a relationship often referred to as the (nutrient) "growth law" (for a review on this topic, see (28) or the very detailed (29)). However, while in E. coli cell width varies greatly (up to $100 \%)$ and concomitantly with cell length $(26,30-32)$, B. subtilis cells adjust their length but maintain a virtually constant diameter regardless of the growth conditions (32-36). This remarkable consistency suggests that cell width is a physiological parameter somehow encrypted in the genome of B. subtilis, and that it must be carefully monitored during growth to correct for potential deviations to its nominal value. Yet how rod-shaped bacteria check and balance their diameter remains unclear. Recently, Garner and co-workers showed that the cell diameter results from the balance between the opposite activities of the Rod and aPBPs elongation machineries (7). They proposed a model in which aPBPsmediated isotropic insertion of unoriented strands into the PG meshwork enlarges the cell cylinder while Rod complex-mediated organized circumferential insertion of PG strands reduces it (7). According to this model, the observation of thinner B. subtilis cells in the absence of aPBPs (37-39), can be explained as the result of the imbalance of the aPBP/Rod complex activities (7). Albeit thinner, cells that rely on the Rod complex for growth retain nevertheless their rod shape, indicating that the 'check \& balance' process of cell width control is still in place. Conversely, reduced activity of the Rod complex leads to the opposite imbalance, driving to an increased cell diameter (7). In absence of 
95 the essential (or co-essential) component(s) of the Rod complex, this ultimately leads to spherical cells, as exemplified by the depletion of RodA, MreC, MreD, PBP2A/PbpH or MreB/Mbl/MreBH (13, 40-43). In agreement with this model, most genes reported to affect cell width in B. subtilis are directly involved in CW homeostasis, affecting one of the competing PG-synthesizing machineries, PG hydrolysis (required to allow PG expansion) or TAs synthesis (Table S1). Other genes previously reported to affect width encode proteins whose absence perturbs the production or the localization of the latter (Table S1).

Here, we aimed at identifying at the genome scale level additional determinants of cell width control during rapid exponential growth. We screened a complete organized collection of $B$. subtilis deletion mutants (24) using High-Content Screening microscopes (HCSm). Our protocol for mid-throughput analysis allowed us to uncover several new genes that may work to maintain cell diameter. These are involved in several cellular processes including CW synthesis, cell division, metabolism, and translation, suggesting that cell width homeostasis results from the combined action of several cellular circuits. Among these, our analysis suggests that metabolism and CW homeostasis are the two main routes affecting cell width. 
Results

\section{Bacillus subtilis cells display limited width variability during rapid exponential growth}

112 It has long been accepted that, in contrast to $E$. coli, the cell diameter of $B$. subtilis cells remains

virtually constant regardless of the growth rate $(32,33)$. We wondered how variable the cell diameter plugin (44-46), to perform cell segmentation and quantify cell diameter (see 'Material and methods', Table S2, Sup. Information). We first compared six independently acquired datasets of wild type $B$. subtilis cells grown to exponential phase in rich LB medium. We observed that the average width remained remarkably constant between experiments (variability below $2 \%$; Fig. 1A and Table S3). Also, the cell-to-cell variability (standard deviation) of the measured width in each population remained low, ranging from 0.071 to $0.089 \mu \mathrm{m}$ across the different replicates (Table S3). These variations might reflect true differences of cell diameter or just the error of our measurements, but in either case variability was low. This reproducibility allowed us to expect the detection of potentially small variations of cell diameter between mutant strains. We next compared the diameter of $B$. subtilis cells exponentially growing in two different media, rich (LB) and poor (S), and thus supporting different growth rates. In agreement with previous reports $(32,33,36)$, we found no significant difference of width between cells grown in rich and poor media (Fig. 1B). The cell-to-cell variability was similar in the two media, indicating that this variability is independent of the growth rate. Taken together, these experiments indicated that B. subtilis exerts a tight control over its diameter, whose variability remains below $2 \%$ in average across conditions and replicates. genome-scale deletion library of B. subtilis. First, cells were fixed to obtain snapshots of their dimensions during exponential growth. Fixation induces a slight reduction of cell width relative to live cells (Fig. S1A), but prevents issues resulting from the time required for the preparation and imaging 
of 96-well plates with HCSm. Second, the growth medium was supplemented with $20 \mathrm{mM}$ of $\mathrm{MgSO}_{4}$ to prevent potential inaccurate estimation of the cell diameter of mutants displaying irregular shapes or lysing. In B. subtilis, millimolar concentrations of magnesium in the growth medium are known to reduce the activity of PG hydrolases (47) and to alleviate the morphological defects of mutants affected in PG synthesis (48-50), allowing propagation of otherwise lethal mutations. Importantly, in the presence of high magnesium these mutants display a normal rod shape but still present an abnormal width $(48,49)$. Addition of $\mathrm{Mg}^{2+}$ to the growth medium slightly reduced the average width of wild type cells (Fig. S1B), as previously reported (37). Our ability to detect these slight width differences when cells were either fixed (Fig. S1A) or grown in high magnesium (Fig. S1B) confirmed the sensitivity of our assay to detect small variations of average width between populations.

To further demonstrate the sensitivity of our assay, we tested the $m r e B$ and ponA null mutants, known to be wider and thinner, respectively, than wild type cells $(38,51)$. As shown in Figure 1C, the altered width of $\triangle m r e B$ and $\triangle p o n A$ mutants was unambiguously detected when cells were grown in high $\mathrm{Mg}^{2+}$, fixed and observed in either our conventional epifluorescence microscope or the HCSm. The cell-to-cell variability and the average cell widths noticeably increased when measurements were performed on HCSm-acquired images but the relative difference of width between the two mutant strains and the wild type were perfectly conserved (Fig. 1C). These control experiments showed that mutants affected for the control of width could be identified in our medium-throughput HCSm approach.

Next, we screened the complete B. subtilis kanamycin-marked ordered deletion library (BKK) (24), which contains 3983 single-gene deletion mutants ( $93 \%$ open reading frames coverage) of the parental 168 strain (GenBank A1009126) (Fig. 2, see 'Materials and methods' for details). In order to prevent plate-to-plate fluctuations and to compare the widths of the mutants across plates, the width of each mutant was expressed relative to the average cell diameter per plate (ADP, see 'Materials and methods'). The average of the ADPs of the 48 plates (Fig. S2A) and the average cell width of the wild type strain grown and imaged in the same conditions showed no significant difference (Fig. S2B). For each single mutant, we calculated the delta between its average width and the ADP of its plate (Table 

S4). The $3983 \Delta$ width obtained display a Gaussian distribution, spreading from -13.9 to $+23.4 \%$ but with $90 \%$ of the values comprised in a narrow $+/-5 \%$ variation to the mean (Fig. 3A). Next, we arbitrarily set up a cutoff of the $1 \%$ most affected strains ( $0.5 \%$ largest and $0.5 \%$ thinnest) (Fig. 3A). The 40 mutants selected displayed a difference in diameter ranging from 8.9 to $23.4 \%$ to that of their ADP (Table S5, 'screening step'). Using low-throughput epifluorescence microscopy imaging and the wild type $B$. subtilis strain as a reference, we checked the cell width phenotype of the selected mutants (Fig. 2, see also 'Materials and methods'), while the deletion in each mutant was verified by PCR. Two of the strains in the collection were wild type for the tested loci (Table S5) and were discarded for further analysis. A quarter of the mutants displayed a $\Delta$ width $\leq 2 \%$, i.e. equivalent to the variability between wild type replicates (Fig. 1A; Table S3), suggesting that our HCSm analysis yielded some false positives (Table S5, 'checking step'). All 38 confirmed-knockout mutants were nevertheless back-crossed into the wild type background (Fig. 2, Table S6) before attempting further characterization, in order to exclude phenotypes unlinked to the candidate gene deletions.

\section{Cell wall and central carbon metabolism genes are linked to cell width control}

Next, we carefully measured the diameter of the backcrossed mutants (Table S5, 'post-backcross step'). A large reduction of the $\Delta$ width compared to that of the parental strain was confirmed for most of them. Choosing a stringent $\Delta$ width cutoff of $8 \%$, we selected 12 mutants significantly and reproducibly (over 3 independent experiments) wider (7) or thinner (5) (Fig. 3B, 3C, Table 1 and Table S5). We additionally kept the $\Delta \min J$ mutant despite its non-significant $\Delta$ width (-1\%) because of the peculiar uneven width affecting some of the cells in this mutant (Fig. 3C). The width phenotypes were conserved for all 13 mutants when grown without magnesium supplementation (Table S5, 'backcross strains without $\mathrm{Mg}^{2+}$ ), confirming that in contrast to cell bulging, swelling and lysis (observed as consequences of CW synthesis impairment), magnesium cannot rescue the alteration of width. This suggests that cell width alteration does not result from uncontrolled PG hydrolytic activity. 
Among the 13 selected mutants (Fig. 3B and C and Table 1), we identified 9 new genes affecting cell width of B. subtilis (ptsH, guaA, panD, ybzH, pyk, yaaA, minJ, dacA, rpe) and confirmed 4 others ( $\operatorname{rodZ}, c w l O$, ftsE, and $f t s X$ ) previously reported to be affected in cell diameter (Table S1; 'this study'). Note that despite not being in the top $1 \%$ of genes retained for further analysis, ponA still displayed a significantly reduced width in the first step of our screen (Table S4), as expected (Fig. 1C). However, $m r e B H$, lytE and $r n y(y m d A)$ did not display a significant width difference in our experimental conditions (Table S4). It should be noted too that a rodZ null mutant is present in the BKK library (24) even though the rodZ gene was originally reported to be essential in B. subtilis (22). We addressed this apparent discrepancy and showed that rodZ is not essential for growth in B. subtilis, at least in the experimental conditions tested. We also confirmed that $\Delta \operatorname{rodZ}$ cells display division defects (52) and found that they display shape alterations in some media, and that this phenotype is influenced by the parental genetic background (see Sup. Information and Fig. S3).

The 9 new cell width determinants identified in our screen belong to different functional categories (Table 1). Interestingly, only one of them, dacA (encoding PBP5, a bPBP involved in PG maturation $(53,54))$, is directly involved in CW homeostasis. The most represented functional category among our newly identified width-deficient mutants is the metabolism (Table 1). One gene, guaA, is involved in purine nucleotide synthesis (encoding the GMP synthetase (55)), and four are part of the central carbon metabolism (Fig. S4): pyk, specifying the pyruvate kinase acting in glycolysis (56); ptsH, encoding HPr, a component of the sugar phosphotransferase system (PTS) (57); panD, involved in coenzyme A biosynthesis (58); and rpe (yloR), predicted to encode the ribulose-P-epimerase (Rpe) of the pentose phosphate pathway. Although the role of rpe has not yet been investigated in B. subtilis, the prediction got a score $>99.91 \%$ using a hidden Markov model-based homology prediction tool (HHpred; $(59,60))$. Noteworthy, while most mutants involved in CW synthesis were wider, all metabolism mutants but rpe were thinner (Fig. 3B, 3C; Table 1). Out of the three remaining genes selected, one is involved in cell division $(\operatorname{minJ}(61,62))$, one in translation (yaaA, encoding a ribosome assembly factor (63)), and one is annotated as a putative transcriptional regulator $(y b z H,(64))$. Using the HHpred homology prediction tool $(59,60)$, we confirmed that $y b z H$ encodes a probable HTH-type 
transcriptional regulator sharing strong structural resemblance with proteins of the ArsR and GntR families or transcriptional repressors. Regulators of the ArsR-type are involved in the stress-response to heavy-metal ions and GntR-family members in various metabolic pathways including fatty acid, amino acid, or gluconate metabolism $(65,66)$.

\section{$\Delta m i n J$ and $\Delta r p e$ display a phenotype of cell diameter instability}

The mutant strains selected in our screen displayed a thinner or a larger mean diameter relative to wild type cells. Although their mean width differs from the wild type, most of these mutants still control their diameter to maintain it constant over generations. However, two of these mutants, $\Delta r p e$ and $\Delta m i n J$, displayed a distinctive large dispersion of width values (Fig 3B, Table S5).

The $\Delta r p e$ mutant from the BKK library (BKK15790) was first selected based on its reduced width ($11.4 \%$ ) during the HCSm analysis (Table S5). Surprisingly, once backcrossed, the $\Delta$ rpe strain (RCL856) displayed the opposite phenotype with an increased width (+11\%) (Fig. 4A; Table S5), nonetheless indicative of a defect of width control. Another striking difference between the two strains was their width dispersion (Fig. 4A). While the BKK $\Delta r p e$ showed thin and regular cell diameters with a dispersion of values similar to the control strain, widths of the backcrossed mutant displayed the largest variability of our dataset (Fig. 4A, Fig. 3B and Table S5). Furthermore, the backcrossed $\Delta r p e$ mutant formed small slow growing colonies while its BKK parent did not (Fig. S5). Taken together, these results suggest that the $\Delta r p e$ mutant present in our BKK collection had acquired some suppressor mutation(s), partially restoring its growth and reducing its width variability.

The second strain with a variable diameter was $\Delta \operatorname{minJ}$ (Fig. 3B and Table S5). This mutant of the "Min" system involved in division site selection, displays reduced septation, leading to long filamentous cells (Fig. 4B) $(52,61)$. Although the average width of $\Delta m i n J$ cells was marginally affected (-1\%), the SD was unusually large, with widths ranging from 0.7 to $1.4 \mu \mathrm{m}$ (Fig. 3B and Fig. 4B). Furthermore, uneven diameters were observed along the lengths of individual $\Delta m i n J$ filamentous cells (Fig. 4B). This phenotype displayed a polarity, with cells progressively widening or thinning 
241 from a cell pole, and affected only a fraction of the population $(19.16 \%, n>428)$, which could explain

242 why it was not previously reported.

Mutants of metabolism and cell wall homeostasis are differently affected in growth and S/V

ratio.

During the phenotypic characterization of the 13 width-deficient mutants selected in our screen, we

noticed a variability of cell length too, with cells of the guaA mutant unambiguously being the shortest

and cells of the minJ mutant forming very long cells (Fig. 3C). We quantified the average length of all mutants and found that to the exception of $c w l O$, they were all significantly longer or shorter than the wild type (Fig. 5A 'Length', Table 1). It should be noted that $\Delta m i n J$ and $\Delta \operatorname{rodZ}$ mutants form minicells (Fig. S6)(22, 67) that were not taken into account in our length quantification. Interestingly, shorter and wider mutants were all related to $\mathrm{CW}$ homeostasis while metabolism mutants were shorter and thinner than the wild type, again to the exception of $\Delta r p e$ (Fig. 3B, 3C, Fig. 5A and Table 1). However, no direct correlation between cell width and length was observed across the strains (Fig. S7). Because cell length -but not width- of $B$. subtilis usually correlates with growth rate (the "growth law") $(26,28)$, we wondered if differences of cell length between the mutants would mirror differences in growth rate. The generation time (GT), determined during mid exponential growth (see 'Materials and methods), showed no significant difference with the GT of the wild type, for CW homeostasis mutants (Fig. 5A 'GT'). However, the metabolism mutants displayed an increased GT of $>63 \%$ relative to the wild type (Fig. 5A). For these strains, the GT strongly correlated with the average cell length $\left(\mathrm{R}^{2}=0.837\right)$ indicating that in such mutants the "growth law" is conserved (Fig. 5B). In contrast, no correlation was observed between their GT and their cell width (Fig. 5B), further indicating that these two parameters are not connected.

Finally, we calculated the surface area $(\mathrm{S})$ to volume $(\mathrm{V})$ ratio of the mutants. This parameter was proposed to be maintained constant in a given condition, as a key determinant of cell shape (68). The 
267 S/V ratio (Fig. 5A 'S/V'), a consequence of the increased width and the subsequent increased cell

268 volume (the length having a limited contribution to it (Fig. 5A 'length', 5B). This S/V reduction is

269 reminiscent of the effect previously reported for fosfomycin-treated bacteria, an antibiotic inhibiting

270 PG biosynthesis (68), and is consistent with the proposed model that reduction of the rate of S growth

271 (i.e when CW synthesis is reduced) increases cell width and reduces S/V (68). In contrast, all

272 metabolism mutants but $\Delta r p e$ displayed a larger S/V as a consequence of the important drop of both

273 width and length affecting the surface and the volume (Fig. 5A and B).

274 Taken together, our results discriminate between two main groups of width-deficient mutants with

275 specific phenotypes. Mutants of metabolic genes (to the exception of the $\Delta r p e$ ) display a reduced width

276 and increased S/V, and are strongly impaired in growth while, conversely, mutants affected in CW

277 homeostasis display an increased width and reduced S/V, but their GT is unaffected relative to the

278 wild type. 


\section{Discussion}

281 Cell width is probably one of the most tightly regulated physiological parameters in B. subtilis (35).

282 However, the mechanisms allowing its fine control remains unclear. Our approach aimed at revealing in a systematic way non-essential genes involved in this process. We confirmed several of the previously reported non-essential genes acting on B. subtilis width control (Table S1) and identified 9 new genes whose deletion strongly affects $B$. subtilis diameter. Since we arbitrarily set up a cutoff to select the most drastically affected mutants (top 1\%), it is likely that additional genes contribute to width control, along with essential genes or genes acting synthetically. A quick survey of our screen data with a less stringent cutoff (top $10 \%$ most affected mutants, Table S4) shows a few dozens of genes involved in CW (e.g. walH, pbpG, lyt G, yocH, murQ, murE...), lipid metabolism (fabI, lipL, $\operatorname{araM}, f a d E \ldots)$ and central carbon metabolism $(t k t, y w j H, c o a A \ldots)$. This list should nevertheless be taken with caution because the two-step verification performed on our top $1 \%$ selection revealed a significant number of false positives, and because the high-throughput-constructed BKK library may contains suppressors, as exemplified in this work with the rpe mutant.

To our knowledge, most genes previously described to affect cell width are directly involved in CW homeostasis (Table S1). The remaining genes $(\sim 1 / 4)$ are involved in a variety of pathways, but they were shown to affect the levels or localization of $\mathrm{CW}$ synthetic proteins or the levels of PG precursors (Table S1). In agreement with this, many mutants identified in our screen are related to CW homeostasis as well. In addition to $c w l O, \operatorname{rodZ}, f t s X$ and $f t s E$, whose mutants were known to display width defects, we identified $d a c A$, encoding the major vegetative DD-carboxypeptidase PBP5, responsible for the maturation of the PG by trimming the terminal D-Ala of the pentapeptide (69).

Unexpectedly, we also identified several genes involved in width control that belong to other functional categories, including five metabolic genes: $p t s H, g u a A, r p e, p y k$ and $p a n D$. So far, the only metabolic gene described to affect cell width was $g \operatorname{lm} R$, which encodes a regulator controlling the carbon flux that stimulates the PG precursor synthetic pathway in neoglucogenic conditions $(70,71)$. were affected in cell length (reviewed in (28)). Out of these, only pyk, encoding PykA, which produces 
pyruvate in the final step of glycolysis (Fig. S4), was identified in our screen, which may suggest a central role for this protein to coordinate the cell metabolic status with the control of length/division and width/elongation.

Another salient point of the study is that the two main groups of width-deficient mutants are discriminated by their phenotypes. Genes involved in CW homeostasis display an increased width and a reduced S/V but unaffected growth rate, while metabolism mutants display a reduced width and an increased $\mathrm{S} / \mathrm{V}$, and their growth rate is strongly affected. Based on these observations, it is tempting to speculate that $y a a A$ is somehow involved in $\mathrm{CW}$ homeostasis while $y b z H$ function may be directly or indirectly related to a metabolic pathway. In this dichotomy, rpe is stepping out, sharing characteristics of both groups and thus suggesting that its phenotypes might reflect a defect in both pathways. This hypothesis is strengthen by the presence of genes connected with cell shape control in the same operon than rpe: $\operatorname{prpC}$, prkC and $\operatorname{pg} g$. PrkC is a Ser/Thr kinase -and PrpC its cognate Ser/Thr phosphatase- regulating many proteins including some reported to affect cell width in B. subtilis as LtaS, YfnI, YqgS (72), CpgA (73), GlmR (YvcK) (74), RodZ (75) and GpsB (76) (Table S1). CpgA was recently shown to moonlight as a detoxifying enzyme of erythronate-4P, whose accumulation induces a depletion of fructose-6P, the entry of the PG precursor pathway (77). Thus, the rpe operon may be at the crossroad between the metabolic and CW homeostasis pathways. coworkers (68). They proposed a 'relative rate' model in which the rates of S and V growth are both functions of $\mathrm{V}$ (and not functions of $\mathrm{S}$ and $\mathrm{V}$, respectively) and that $\mathrm{S} / \mathrm{V}$ is the key parameter maintained constant in a given condition rather that the respective rates of $\mathrm{S}$ and $\mathrm{V}$ expansion (68). $\mathrm{A}$ consequence of their model is that a diminishing rate of S growth, for example when reducing the $\mathrm{CW}$ synthesis, both increases cell width and reduces $\mathrm{S} / \mathrm{V}$, even for a constant growth rate. Thus, one could hypothesizes that the increase of width observed in the mutants identified in our screen may be a direct consequence of a crippled cell surface synthesis. 
334 (7). According to this model, the CW mutants selected in this study (dacA, ftsE, fts $X, c w l O$ and $\operatorname{rodZ}$ )

335 would present an unbalanced PG-synthesizing activity in favor of the aPBPs. Following the same line

336 of thought, the metabolism mutants identified in this study, slender (to the exception of rpe), should

337 present the opposite imbalance, with increased activity of the Rod complex or decreased activity of

338 aPBPs.

339 In summary, cell with control appears as a very tightly regulated process in which different cellular

340 circuits are at play. Our results indicate that metabolism is a major contributor to the control of cell

341 width, suggesting the presence of unsuspected regulators or moonlighters affecting the synthesis of the

$342 \mathrm{CW}$. Among the genes identified here, 3 are stepping out and are of particular interest. On the one

343 hand, RodZ acts on both cell division and elongation, and its activity depends on the medium

344 composition (Fig. S3), strengthening a possible link between metabolism/width. On the other hand,

$345 \operatorname{minJ}$ and rpe mutant cells display unique uncontrolled width suggesting that the 'check and balance'

346 of width control is lost. Deciphering how these genes affect the control of cell width of $B$. subtilis will

347 be a challenge for future research. 
351 General methods and bacterial growth conditions. Methods for growth of B. subtilis,

352 transformation, selection of transformants and so on have been described extensively elsewhere (78).

353 DNA manipulations were carried out by standard methods. B. subtilis strains used in this study are

354 listed in Table S6. B. subtilis strains were grown at $30{ }^{\circ} \mathrm{C}$ or $37^{\circ} \mathrm{C}$ in rich lysogeny broth medium

355 (LB), except for assaying growth in poor media, where strains were grown in Modified Salt Medium 356 (MSM) supplemented with $10 \mathrm{mM} \mathrm{MgSO}_{4}$ (48) and S medium (33) with the corrected $1.2 \mu \mathrm{g} / \mathrm{ml}$ of

$357 \mathrm{MnSO}_{4}$. For precultures, media supplements were added at the following final concentrations: $\mathrm{MgSO}_{4}$

$35820 \mathrm{mM}$, neomycin $15 \mu \mathrm{g} \cdot \mathrm{ml}^{-1}$, spectinomycin $100 \mu \mathrm{g} \cdot \mathrm{ml}^{-1}$ or chloramphenicol $5 \mu \mathrm{g} \cdot \mathrm{ml}^{-1}$ (Table S6).

359 Transformants were selected on $\mathrm{LB}$ agar plates supplemented with $\mathrm{MgSO}_{4}$ and neomycin. For the

360 determination of generation time (GT), cells from overnight cultures were diluted to a fixed starting

$361 \mathrm{OD}_{600 \mathrm{~nm}}$ of 0.01 in fresh $\mathrm{LB}$ medium supplemented with $\mathrm{MgSO}_{4}$ in 96-well cell culture plates

362 (CellStar) and grown in a microplate reader Synergy2 (BioTek Instruments, Vt, USA) at maximum

$363 \mathrm{rpm}$ at $37^{\circ} \mathrm{C}$. GT was calculated using a Matlab script available at the following link:

364 https://github.com/CyrilleBillaudeau/GenerationTime_ofBacteria_withOD.

366 General screening procedure. Our screening was performed on the BKK library (24) using HCSm

367 setups (see 'High content screening microscopy'), leading to the selection of 3974 out of the 3983

368 mutants from this collection (9 clones were absent from the published library or failed to re-grow).

369 Images were processed and the cell diameter was measured (see 'Image processing and cell size

370 quantification'). The $1 \%$ most affected strains (40 mutants) were selected and their phenotype

371 confirmed using an epifluorescence microscope (see 'Low throughput epifluorescence microscopy'

372 and 'Image processing and cell size quantification'). Deletions in the selected clones were verified by

373 PCR, revealing that 2 mutants $(y o q C$, yor $P$ ) were wild type for the expected locus and thus they were

374 discarded for further analysis. The remaining 38 mutants were back-crossed into the wild type 168 
strain to be analyzed over triplicate experiments using low throughput microscopy. An arbitrary cutoff of $8 \% \Delta$ width, obtained by comparison to the wild type strain width, was chosen and 12 genes were finally selected.

High content screening microscopy. Cells from overnight cultures, grown in the presence of neomycin and $\mathrm{MgSO}_{4}$, were diluted at $1 / 600$ in fresh $\mathrm{LB}$ medium supplemented with $\mathrm{MgSO}_{4}$ in 96well cell culture plates (CellStar) and grown on an orbital shaker at $250 \mathrm{rpm}$ at $37^{\circ} \mathrm{C}$ until midexponential phase $\left(\mathrm{OD}_{600} \sim 0.2\right)$. To fix the cells, $150 \mu \mathrm{L}$ of culture were mixed with $50 \mu \mathrm{L}$ of fixation solution $\left(0.5 \mathrm{M} \mathrm{KPO}_{4} \mathrm{pH} \mathrm{7,} 8 \%\right.$ paraformaldehyde, $0.08 \%$ glutaraldehyde) in 96-well PCR plates and incubated $15 \mathrm{~min}$ at room temperature followed by $15 \mathrm{~min}$ on ice. The cells were pelleted by a $5 \mathrm{~min}$ centrifugation at $450 \mathrm{~g}$, and the supernatant carefully removed by pipetting. The pellets were washed with $200 \mu \mathrm{L}$ of washing buffer $\left(\mathrm{KPO}_{4} 0.1 \mathrm{M} \mathrm{pH}\right.$ 7), centrifuged again, resuspended in $20 \mu \mathrm{L}$ of water containing $3.3 \mu \mathrm{g} / \mathrm{mL} \mathrm{FM}^{\mathrm{TM}} 1-43 \mathrm{FX}$ (ThermoFisher, F35355) and incubated $5 \mathrm{~min}$ at room temperature. $180 \mu \mathrm{L}$ of washing buffer were added and the cells were centrifuged a last time to be concentrated $3.75 \times$ in $40 \mu \mathrm{L}$ washing buffer. 96-well (Fisher) or 384-well (Greiner) microscopy plates were treated with $60 \mu \mathrm{L}$ of poly-L-lysine $0,01 \%$ and washed with $60 \mu \mathrm{L}$ of deionized water. 40 $\mu \mathrm{L}$ of cells were put in each well and discarded after a 1 min incubation. Finally, 40 or $120 \mu \mathrm{L}$ of deionized water were added into each well of 96-well or 384-well plates. Imaging was performed either on an ImageXpress micro Confocal (Molecular Devices) or an IN Cell 6000 Analyzer (GE Healthcare) used in non-confocal mode. The ImageXpress HCS microscope was equipped with a $60 \times$ Nikon air objective (NA 0.95), a FITC filter (Ex.488/Em.536) and a Zyla 4.2 Andor sCMOS camera with a final pixel size of $115 \mathrm{~nm}$ and controlled by MetaXpress software package. The INCell 6000 analyzer was equipped with a $60 \times$ water objective (NA 0.95), a FITC filter (Ex.488/Em.525) and a sCMOS 5.5 Mpixels camera with a final pixel size of $108 \mathrm{~nm}$ and controlled by the INCell 6000 Analyzer - Acquisition v.7.1 Software. Images from 4 fields of view were acquired for each strain. 
Low throughput epifluorescence microscopy. Cultures were performed as for HCS microscopy but

402 in shaking tubes instead of microplates. For live cell imaging, $300 \mu \mathrm{L}$ of cultures were directly mixed with $\mathrm{FM}^{\mathrm{TM}} 1-43 \mathrm{FX}$ (ThermoFisher) to reach the concentration of $3.3 \mu \mathrm{g} / \mathrm{mL}$ and concentrated $3.75 \times$ before $1 \mu \mathrm{L}$ of the preparation was spotted onto a thin $2 \%$ agarose-LB pad, topped by a coverslip and immersion oil, and mounted immediately in the temperature-controlled microscope stage. For the imaging of fixed cells, cells were fixed as described for HCS microscopy except that $300 \mu \mathrm{L}$ of culture were mixed with $100 \mu \mathrm{L}$ of fixation solution and subsequently washed with $300 \mu \mathrm{L}$ of buffer. Cells were spotted on a $2 \%$ agarose-LB pad or on poly-L-lysine-treated 96 well microscopy plate. For the latter, the wells were washed then filled with deionized water. Epifluorescence images of the membrane-stained cells were acquired on a previously described setup equipped with a $100 \times$ objective (36).

Image processing and cell size quantification. The post-acquisition treatment of the images was done with the Fiji software and the measures (mean cell diameter and length) with the MicrobeJ plugin (44-46). In MicrobeJ, the cell width was calculated as the mean value along the medial axis of the cell. The parameters used for the MicrobeJ module are listed in Table S2. Cells aggregates were excluded and segmentation was manually corrected when necessary.

During high-throughput screening, the cell width of each strain was calculated as the mean of 225 cells (in average). When the four-image set contained less than 30 measurable cells, a new acquisition was performed. Because the library is devoid of a wild type reference, and to prevent putative plate-toplate variability, the mean cell width of each mutant was compared to the average width of all measured cells of its 96-well plate, the ADP (average cell diameter per plate) index (17-19.10 cells/plate) (Fig. S2A). Each strain's diameter deviation relatively to this index was calculated, as:

$$
\Delta \text { width }(\%)=(\text { mean width of the mutant }- \text { ADP }) \times 100 / \text { ADP }
$$

From these differences, the $0.5^{\text {st }}$ and $99.5^{\text {th }}$ percentile were calculated and the $99 \%$ of the mutants between these two values eliminated. 
During low-throughput microscopy (for the verification of the BKK candidates and for clones

427

resulting from the backcross into the 168 strain) the cell width and length of each strain was calculated as the mean of 245 cells (in average). The calculated $\Delta$ width was expressed by comparison with the wild type cell size.

\section{Alternative methods for cell width measurement. Cell widths were measured either with the} ChainTracer plugin of the Fiji software, or by determining "manually" the width at maximum height on intensity profiles (79) (Fig. S1). For ChainTracer, we used a stack of phase contrast and epifluorescence images of membrane-stained cells, and only analyzed isolated chains of cells to prevent segmentation issues. For the measurement using intensity profiles, a line was manually drawn perpendicularly to the cell's long axis, on epifluorescence images of stained membranes, and a profile plot of the fluorescence intensity was generated. The cell diameter was determined by measuring the distance between the two maxima.

Statistical analysis. All statistical analyses were performed with Prism 9 (GraphPad Software, LLC). To analyze the variance between replicates, a multiple (pairwise) comparison was performed using one-way ANOVA (Fig. 1A). For pairwise comparison between means of a control and its tested sample with 2 or more replicates, we performed nested t-tests (Fig. 1B, 1C, 3B, 4A, 5A_'length', 5A_'S/V'). Note that the plots show the pooled values of the replicates. When t-tests were not possible (e.g. if $\mathrm{N}<30$ ), pairwise comparisons were done with a non-parametric Mann-Whitney test (Fig. 5A_'GT'). $P$-values are displayed as follows: $* * * *=\mathrm{P}<0.0001 ; * * *=0.0001<\mathrm{P}<0.001$; $* *=$ $0.001<\mathrm{P}<0.01 ; *=0.01<\mathrm{P}<0.05 ; \mathrm{ns}=\mathrm{P}>0.05$.

\section{Acknowledgments.}



made available under aCC-BY-NC-ND 4.0 International license.

450 This project has received funding from the European Research Council (ERC) under the European

451 Union's Horizon 2020 research and innovation program (grant agreement No 311231 and grant

452 agreement No 772178, to R.C.-L.). We thank Alexandre Vandeputte and the BioImaging Center Lille-

453 Nord de France (BICeL) facility (Lille, France) for HCSm acquisitions. Financial support for the HCS

454 equipment was provided by the FEDER (12001407 (D-AL) Equipex Imaginex BioMed).

455 
457 1. Young KD. 2006. The selective value of bacterial shape. Microbiol Mol Biol Rev 70:660-703.

458 2. Brown S, Santa Maria JP, Jr., Walker S. 2013. Wall teichoic acids of gram-positive bacteria. Annu 459 Rev Microbiol 67:313-36.

460 3. Rohde M. 2019. The Gram-Positive Bacterial Cell Wall. Microbiol Spectr 7.

461 4. Egan AJF, Errington J, Vollmer W. 2020. Regulation of peptidoglycan synthesis and remodelling. Nature Reviews Microbiology 18:446-460.

5. van Teeffelen S, Renner LD. 2018. Recent advances in understanding how rod-like bacteria stably maintain their cell shapes. F1000Research 7:241.

6. Cho H, Wivagg CN, Kapoor M, Barry Z, Rohs PDA, Suh H, Marto JA, Garner EC, Bernhardt TG. 2016. Bacterial cell wall biogenesis is mediated by SEDS and PBP polymerase families functioning semi-autonomously. Nature Microbiology 1.

7. Dion MF, Kapoor M, Sun Y, Wilson S, Ryan J, Vigouroux A, van Teeffelen S, Oldenbourg R, Garner EC. 2019. Bacillus subtilis cell diameter is determined by the opposing actions of two distinct cell wall synthetic systems. Nat Microbiol 4:1294-1305.

8. Vigouroux A, Cordier B, Aristov A, Alvarez L, Ozbaykal G, Chaze T, Oldewurtel ER, Matondo M, Cava F, Bikard D, van Teeffelen S. 2020. Class-A penicillin binding proteins do not contribute to cell shape but repair cell-wall defects. Elife 9.

473

9. Emami K, Guyet A, Kawai Y, Devi J, Wu LJ, Allenby N, Daniel RA, Errington J. 2017. RodA as the missing glycosyltransferase in Bacillus subtilis and antibiotic discovery for the peptidoglycan polymerase pathway. Nature Microbiology 2.

10. McPherson DC, Popham DL. 2003. Peptidoglycan synthesis in the absence of class A penicillinbinding proteins in Bacillus subtilis. J Bacteriol 185:1423-31.

11. Patel Y, Zhao H, Helmann JD. 2020. A regulatory pathway that selectively up-regulates elongasome function in the absence of class A PBPs. Elife 9.

12. Meeske AJ, Riley EP, Robins WP, Uehara T, Mekalanos JJ, Kahne D, Walker S, Kruse AC, Bernhardt TG, Rudner DZ. 2016. SEDS proteins are a widespread family of bacterial cell wall polymerases. Nature 537:634-638.

13. Wei Y, Havasy T, McPherson DC, Popham DL. 2003. Rod shape determination by the Bacillus subtilis class B penicillin-binding proteins encoded by $p b p A$ and $p b p H$. J Bacteriol 185:4717-26.

14. Carballido-Lopez R. 2017. The Actin-like MreB 'Cytoskeleton', p 223-262. In Graumann PL (ed), Bacillus: Cellular and Molecular Biology (Third edition), vol 1. Caister Academic Press.

15. Hussain $S$, Wivagg CN, Szwedziak $P$, Wong F, Schaefer $K$, Izore $T$, Renner LD, Holmes MJ, Sun $Y$, Bisson-Filho AW, Walker S, Amir A, Lowe J, Garner EC. 2018. MreB filaments align along greatest principal membrane curvature to orient cell wall synthesis. Elife 7.

16. Carballido-López R, Formstone A, Li Y, Ehrlich SD, Noirot P, Errington J. 2006. Actin homolog MreBH governs cell morphogenesis by localization of the cell wall hydrolase LytE. Dev Cell 11:399-409.

17. Kawai Y, Asai K, Errington J. 2009. Partial functional redundancy of MreB isoforms, MreB, Mbl and MreBH, in cell morphogenesis of Bacillus subtilis. Mol Microbiol 73:719-31.

18. Alyahya SA, Alexander R, Costa T, Henriques AO, Emonet T, Jacobs-Wagner C. 2009. RodZ, a component of the bacterial core morphogenic apparatus. Proceedings of the National Academy of Sciences 106:1239-1244.

19. Bendezu FO, Hale CA, Bernhardt TG, de Boer PA. 2009. RodZ (YfgA) is required for proper assembly of the MreB actin cytoskeleton and cell shape in E. coli. The EMBO Journal 28:193204.

20. Shiomi D, Sakai M, Niki H. 2008. Determination of bacterial rod shape by a novel cytoskeletal membrane protein. The EMBO Journal 27:3081-3091.

21. van den Ent F, Johnson CM, Persons L, de Boer P, Lowe J. 2010. Bacterial actin MreB assembles in complex with cell shape protein RodZ. Embo J 29:1081-90. 
22. Muchová K, Chromiková Z, Barák I. 2013. Control of Bacillus subtilis cell shape by RodZ. Environmental Microbiology 15:3259-3271.

23. Kobayashi K, Ehrlich SD, Albertini A, Amati G, Andersen KK, Arnaud M, Asai K, Ashikaga S, Aymerich S, Bessieres P, Boland F, Brignell SC, Bron S, Bunai K, Chapuis J, Christiansen LC, Danchin A, Debarbouille M, Dervyn E, Deuerling E, Devine K, Devine SK, Dreesen O, Errington J, Fillinger S, Foster SJ, Fujita Y, Galizzi A, Gardan R, Eschevins C, Fukushima T, Haga K, Harwood CR, Hecker M, Hosoya D, Hullo MF, Kakeshita H, Karamata D, Kasahara Y, Kawamura F, Koga K, Koski P, Kuwana R, Imamura D, Ishimaru M, Ishikawa S, Ishio I, Le Coq D, Masson A, Mauel C, et al. 2003. Essential Bacillus subtilis genes. Proc Natl Acad Sci U S A 100:4678-83.

24. Koo BM, Kritikos G, Farelli JD, Todor H, Tong K, Kimsey H, Wapinski I, Galardini M, Cabal A, Peters JM, Hachmann AB, Rudner DZ, Allen KN, Typas A, Gross CA. 2017. Construction and Analysis of Two Genome-Scale Deletion Libraries for Bacillus subtilis. Cell Syst 4:291-305 e7.

25. van Beilen J, Blohmke CJ, Folkerts H, de Boer R, Zakrzewska A, Kulik W, Vaz FM, Brul S, Ter Beek A. 2016. RodZ and PgsA Play Intertwined Roles in Membrane Homeostasis of Bacillus subtilis and Resistance to Weak Organic Acid Stress. Front Microbiol 7:1633.

26. Schaechter M, Maaloe O, Kjeldgaard N. 1958. Dependency on medium and temperature of cell size and chemical composition during balanced grown of Salmonella typhimurium. J Gen Microbiol 19:592-606.

27. Henrici AT. 1928. Morphologic variation and the rate of growth of bacteria, vol 1. Thomas, Charles C.

28. Vadia S, Levin PA. 2015. Growth rate and cell size: a re-examination of the growth law. Curr Opin Microbiol 24:96-103.

29. Jun S, Si F, Pugatch R, Scott M. 2018. Fundamental principles in bacterial physiology-history, recent progress, and the future with focus on cell size control: a review. Rep Prog Phys 81:056601.

30. Grover NB, Woldringh CL, Zaritsky A, Rosenberger RF. 1977. Elongation of rod-shaped bacteria. J Theor Biol 67:181-93.

31. Taheri-Araghi S, Bradde S, Sauls JT, Hill NS, Levin PA, Paulsson J, Vergassola M, Jun S. 2015. Cell-size control and homeostasis in bacteria. Curr Biol 25:385-91.

32. Trueba FJ, Woldringh CL. 1980. Changes in cell diameter during the division cycle of Escherichia coli. Journal of bacteriology 142:869-878.

33. Sharpe ME, Hauser PM, Sharpe RG, Errington J. 1998. Bacillus subtilis cell cycle as studied by fluorescence microscopy: constancy of cell length at initiation of DNA replication and evidence for active nucleoid partitioning. J Bacteriol 180:547-55.

34. Weart RB, Lee AH, Chien AC, Haeusser DP, Hill NS, Levin PA. 2007. A metabolic sensor governing cell size in bacteria. Cell 130:335-47.

35. Sauls JT, Cox SE, Do Q, Castillo V, Ghulam-Jelani Z, Jun S. 2019. Control of Bacillus subtilis Replication Initiation during Physiological Transitions and Perturbations. mBio 10.

36. Billaudeau C, Chastanet A, Yao Z, Cornilleau C, Mirouze N, Fromion V, Carballido-Lopez R. 2017. Contrasting mechanisms of growth in two model rod-shaped bacteria. Nat Commun 8:15370.

37. Claessen D, Emmins R, Hamoen LW, Daniel RA, Errington J, Edwards DH. 2008. Control of the cell elongation-division cycle by shuttling of PBP1 protein in Bacillus subtilis. Mol Microbiol 68:1029-46.

38. Popham DL, Setlow P. 1996. Phenotypes of Bacillus subtilis mutants lacking multiple classA high-molecular-weight penicillin-binding proteins. Journal of bacteriology 178:2079-2085.

39. Popham DL, Young KD. 2003. Role of penicillin-binding proteins in bacterial cell morphogenesis. Curr Opin Microbiol 6:594-9.

40. Henriques AO, Glaser P, Piggot PJ, Moran CP, Jr. 1998. Control of cell shape and elongation by the $\operatorname{rodA}$ gene in Bacillus subtilis. Mol Microbiol 28:235-47.

41. Lee JC, Stewart GC. 2003. Essential nature of the mreC determinant of Bacillus subtilis. J Bacteriol 185:4490-8. 
42. Leaver M, Errington J. 2005. Roles for MreC and MreD proteins in helical growth of the cylindrical cell wall in Bacillus subtilis. Mol Microbiol 57:1196-209.

43. Schirner K, Errington J. 2009. The cell wall regulator \{sigma\}l specifically suppresses the lethal phenotype of mbl mutants in Bacillus subtilis. J Bacteriol 191:1404-13.

44. Ducret A, Quardokus EM, Brun YV. 2016. MicrobeJ, a tool for high throughput bacterial cell detection and quantitative analysis. Nature Microbiology 1.

45. Schindelin J, Arganda-Carreras I, Frise E, Kaynig V, Longair M, Pietzsch T, Preibisch S, Rueden C, Saalfeld S, Schmid B, Tinevez JY, White DJ, Hartenstein V, Eliceiri K, Tomancak P, Cardona A. 2012. Fiji: an open-source platform for biological-image analysis. Nat Methods 9:676-82.

46. Rueden CT, Schindelin J, Hiner MC, DeZonia BE, Walter AE, Arena ET, Eliceiri KW. 2017. ImageJ2: ImageJ for the next generation of scientific image data. BMC Bioinformatics 18:529.

47. Dajkovic A, Tesson B, Chauhan S, Courtin P, Keary R, Flores P, Marliere C, Filipe SR, ChapotChartier MP, Carballido-Lopez R. 2017. Hydrolysis of peptidoglycan is modulated by amidation of meso-diaminopimelic acid and Mg2+ in Bacillus subtilis. Mol Microbiol 104:972-988.

48. Murray T, Popham DL, Setlow P. 1998. Bacillus subtilis cells lacking penicillin-binding protein 1 require increased levels of divalent cations for growth. J Bacteriol 180:4555-63.

49. Formstone A, Errington J. 2005. A magnesium-dependent mreB null mutant: implications for the role of $m r e B$ in Bacillus subtilis. Mol Microbiol 55:1646-57.

50. Chastanet A, Carballido-Lopez R. 2012. The actin-like MreB proteins in Bacillus subtilis: a new turn. Front Biosci (Schol Ed) 4:1582-606.

51. Jones L, Carballido-López R, Errington J. 2001. Control of cell shape in bacteria: helical, actinlike filaments in Bacillus subtilis. Cell 104:913-22.

52. Muchová K, Chromiková Z, Valenčíková R, Barák I. 2018. Interaction of the Morphogenic Protein RodZ with the Bacillus subtilis Min System. Frontiers in Microbiology 8.

53. Todd JA, Roberts AN, Johnstone K, Piggot PJ, Winter G, Ellar DJ. 1986. Reduced heat resistance of mutant spores after cloning and mutagenesis of the Bacillus subtilis gene encoding Penicillin-binding protein 5. Journal of bacteriology 167:257-264.

54. Atrih A, Bacher G, Allmaier G, Williamson MP, Foster SJ. 1999. Analysis of peptidoglycan structure from vegetative cells of Bacillus subtilis 168 and role of PBP 5 in peptidoglycan maturation. Journal of bacteriology 181.

55. Mantsala P, Zalkin H. 1992. Cloning and sequence of Bacillus subtilis purA and guaA, involved in the conversion of IMP to AMP and GMP. J Bacteriol 174:1883-90.

56. Fry B, Zhu T, Domach MM, Koepsel RR, Phalakornkule C, Ataai MM. 2000. Characterization of growth and acid formation in a Bacillus subtilis pyruvate Kknase mutant. Applied and environmental microbiology 66:4045-4049.

57. Gorke B, Stulke J. 2008. Carbon catabolite repression in bacteria: many ways to make the most out of nutrients. Nat Rev Microbiol 6:613-24.

58. Pei W, Zhang J, Deng S, Tigu F, Li Y, Li Q, Cai Z, Li Y. 2017. Molecular engineering of L-aspartatealpha-decarboxylase for improved activity and catalytic stability. Appl Microbiol Biotechnol 101:6015-6021.

59. Soding J. 2005. Protein homology detection by HMM-HMM comparison. Bioinformatics 21:951-60.

60. Zimmermann L, Stephens A, Nam SZ, Rau D, Kubler J, Lozajic M, Gabler F, Soding J, Lupas AN, Alva V. 2018. A Completely Reimplemented MPI Bioinformatics Toolkit with a New HHpred Server at its Core. J Mol Biol 430:2237-2243.

61. Patrick JE, Kearns DB. 2008. MinJ (YvjD) is a topological determinant of cell division in Bacillus subtilis. Mol Microbiol 70:1166-79.

62. Bramkamp M, Emmins R, Weston L, Donovan C, Daniel RA, Errington J. 2008. A novel component of the division-site selection system of Bacillus subtilis and a new mode of action for the division inhibitor MinCD. Mol Microbiol 70:1556-69.

63. Suzuki S, Tanigawa O, Akanuma G, Nanamiya H, Kawamura F, Tagami K, Nomura N, Kawabata T, Sekine Y. 2014. Enhanced expression of Bacillus subtilis yaaA can restore both the growth 
and the sporulation defects caused by mutation of $r p / B$, encoding ribosomal protein L2. Microbiology (Reading) 160:1040-1053.

64. Rasmussen S, Nielsen HB, Jarmer H. 2009. The transcriptionally active regions in the genome of Bacillus subtilis. Mol Microbiol 73:1043-57.

65. Busenlehner LS, Pennella MA, Giedroc DP. 2003. The SmtB/ArsR family of metalloregulatory transcriptional repressors: Structural insights into prokaryotic metal resistance. FEMS Microbiol Rev 27:131-43.

66. Hoskisson PA, Rigali S. 2009. Chapter 1: Variation in form and function the helix-turn-helix regulators of the GntR superfamily. Adv Appl Microbiol 69:1-22.

67. van Baarle S, Bramkamp M. 2010. The MinCDJ system in Bacillus subtilis prevents minicell formation by promoting divisome disassembly. PLoS One 5:e9850.

68. Harris LK, Theriot JA. 2016. Relative Rates of Surface and Volume Synthesis Set Bacterial Cell Size. Cell 165:1479-1492.

69. Vollmer W, Joris B, Charlier P, Foster S. 2008. Bacterial peptidoglycan (murein) hydrolases. FEMS Microbiol Rev 32:259-86.

70. Foulquier E, Pompeo F, Bernadac A, Espinosa L, Galinier A. 2011. The YvcK protein is required for morphogenesis via localization of PBP1 under gluconeogenic growth conditions in Bacillus subtilis. Mol Microbiol 80:309-18.

71. Patel V, Wu Q, Chandrangsu P, Helmann JD. 2018. A metabolic checkpoint protein GImR is important for diverting carbon into peptidoglycan biosynthesis in Bacillus subtilis. PLoS Genet 14:e1007689.

72. Pompeo F, Rismondo J, Grundling A, Galinier A. 2018. Investigation of the phosphorylation of Bacillus subtilis LTA synthases by the serine/threonine kinase PrkC. Sci Rep 8:17344.

73. Absalon C, Obuchowski M, Madec E, Delattre D, Holland IB, Seror SJ. 2009. CpgA, EF-Tu and the stressosome protein YezB are substrates of the Ser/Thr kinase/phosphatase couple, PrkC/PrpC, in Bacillus subtilis. Microbiology (Reading) 155:932-943.

74. Foulquier E, Pompeo F, Freton C, Cordier B, Grangeasse C, Galinier A. 2014. PrkC-mediated phosphorylation of overexpressed YvcK protein regulates PBP1 protein localization in Bacillus subtilis mreB mutant cells. J Biol Chem 289:23662-9.

75. Ravikumar V, Shi L, Krug K, Derouiche A, Jers C, Cousin C, Kobir A, Mijakovic I, Macek B. 2014. Quantitative phosphoproteome analysis of Bacillus subtilis reveals novel substrates of the kinase PrkC and phosphatase PrpC. Mol Cell Proteomics 13:1965-78.

76. Pompeo F, Foulquier E, Serrano B, Grangeasse C, Galinier A. 2015. Phosphorylation of the cell division protein GpsB regulates PrkC kinase activity through a negative feedback loop in Bacillus subtilis. Mol Microbiol 97:139-50.

77. Sachla AJ, Helmann JD. 2019. A bacterial checkpoint protein for ribosome assembly moonlights as an essential metabolite-proofreading enzyme. Nat Commun 10:1526.

78. Harwood CR, Cutting SM. 1990. Molecular biological methods for Bacillus. J. Wileys and Sons.

79. Syvertsson S, Vischer NO, Gao Y, Hamoen LW. 2016. When Phase Contrast Fails: ChainTracer and NucTracer, Two ImageJ Methods for Semi-Automated Single Cell Analysis Using Membrane or DNA Staining. PLoS One 11:e0151267. 


\section{List of supplementary materials:}

652 - Supplementary information

Comparison of width measurements obtained with different methods

RodZ, a non-essential protein involved in cell shape control

List (names and sequences) of oligonucleotides

656

657

658

659

660

661

662

663

664

665

666

667

668

669

670

671

672

\section{- Supplementary tables}

Table S1. Genes reported to affect cell width in B. subtilis

Table S2. Settings used for MicrobeJ plugin

Table S3. Average width differences (\%) across replicates

Table S4. Cell width of mutants of the BKK collection

Table S5: Width of the $0.5 \%$ largest and thinnest selected strains

Table S6. B. subtilis strains used in this study

\section{- Supplementary figures}

Fig. S1. Comparative cell width distributions of wild type B. subtilis cells.

Fig. S2. ADPs are constant across plates and equal to the width of the wild type strain.

Fig. S3. Growth and cell shape of B. subtilis rodZ mutants vary depending on the growth media and the genetic background.

Fig. S4. Carbon metabolic pathways involving the selected mutants deficient for cell width control.

Fig. S5. Backcross of the rpe deletion reveals a strong growth defect.

Fig. S6. The rodZ and minJ mutants form minicells.

Fig. S7. Average cell lengths as a function of average cell widths for each mutant. 
Sup. Figures legends:

675 Fig. Sup. 1. Comparative cell width distributions of wild type B. subtilis cells. A. Cell width of live and fixed cells were measured using the Fiji plugins MicrobeJ and Chain tracer, or by manual measurements (see 'Materials and methods'). The differences between the means of live and fixed cells (in \%) is specified for each method. B. Comparative cell width distribution of fixed wild type B. subtilis cells grown in LB with and without $20 \mathrm{mM}$ magnesium supplementation. Broken line: mean. Differences between the means, expressed as a percent, are indicated on the plots. Statistical analysis were performed using nested t-tests. Data (A, B) are compilations of at least two independent experiments.

Fig. Sup. 2. ADPs are constant across plates and equal to the width of the wild type strain. A. ADP of the 48 96-well plates containing the BKK library. Each ADP is the mean of all measured cell widths ( 20 000) on a plate, and error bars are the standard deviations (SD). For the $48^{\text {th }}$ plate, the acquisition was performed on the epifluorescence microscope (with 100x magnification) and not on the HCSm, which explains the reduced values (as in Fig. 1C). B. Comparison of the average of the ADPs of all 48 plates and the average width of a wild type cell population measured with the HCSm. There is no significant difference between the two values according to the Mann-Whitney nonparametric test, indicating ADPs are similar to the wild type diameter $(1.160 \mu \mathrm{m}$ vs $1.153 \mu \mathrm{m}$, respectively). Similarly, the ADP calculated for the $48^{\text {th }}$ plate is close to the wild type strain measured in the corresponding microscope $(0.975 \mu \mathrm{m}$ vs $0.964 \mu \mathrm{m}$, respectively). Error bars are SD.

Fig. Sup. 3. Growth and cell shape of $B$. subtilis rodZ mutants vary depending on the growth medium and the genetic background. A-B. Typical growth curves of wild type and $\Delta$ rodZ mutants of B. subtilis in rich LB (blue), poor MSM (green) and S (orange) media. Strains are derivative of the 168 (A) or the PY79 (B) wild type parental strains, and either wild type (plain), or deleted for rodZ 
(dashed; CcBs351 or CcBs628). Panel A displays the growth of two additional $\Delta \operatorname{rodZ}$ mutants, the one from the BKK library (circles; BKK16910) and the BKK $\Delta$ rodZ mutant backcrossed into the 168 wild type strain (dotted; RCL828).

C-D. Epifluorescence images of B. subtilis cells grown to mid exponential growth phase, stained with the FM1-43FX membrane dye. Strains are derivative of the 168 (C) or the PY79 (D) wild type strains, and either wild type ('wt'), carrying our rodZ deletion (CcBs351; CcBs628), rodZ- from the BKK library (BKK16910), or rodZ- from the BKK backcrossed into 168 wild type (RCL828). Scale bars: 1 $\mu \mathrm{m}$.

E-F. Cell width distribution of the rodZ mutants (black) and their parental wild type 168 (E) or PY79 (F) strains (blue), grown to mid exponential phase in LB and MSM media. Data are compilations of two independent experiments. Statistical significance of the comparison between each mutants and the wild type strain was estimated using the Mann-Whitney non-parametric test $(* * * *=P$-value $<0.0001)$.

\section{Fig. Sup. 4. Carbon metabolic pathways involving the selected mutants deficient for cell width}

control. The four genes selected in our screen that are involved in carbon metabolism, panD, ptsH, pyk and rpe, encode enzymes required for the pentothenate, glycolysis and pentose pathways, respectively. PanD converts L-asp into $\beta$-alanine, the first step of the pathway leading to Coenzyme A (Co-A) synthesis. Co-A is used in glycolysis as a substrate for Pyk to form acetyl-CoA. HPr (encoded by $p t s H$ ) is a bi-functional protein acting also in glycolysis as a part of the PTS (phosphotransferase system) required for the import/phosphorylation of sugars, and in the regulation of the carbon catabolite control, as an allosteric regulator with CcpA. Rpe is predicted to produce xylulose-5P in the pentose pathway.

Fig. Sup. 5. Backcross of the rpe deletion reveals a strong growth defect. Chromosomal DNA of strain BKK15790, knockout for rpe, was transformed into the wild type B. subtilis 168 strain (wt) to 

$37^{\circ} \mathrm{C}$.

Fig. Sup. 6. The rodZ and minJ mutants form minicells. Display are images of the $\Delta$ rodZ (strain RCL828) and $\Delta \operatorname{minJ}(\mathrm{RLC} 834)$ mutants grown to mid exponential phase in LB medium, stained with FM1-43FX and fixed, imaged by epifluorescence microscopy. Arrowheads point to minicells. Scale bar: $2 \mu \mathrm{m}$.

Fig. Sup. 7. Average cell length as a function of average cell width for each mutant. The wild type compilations of at least three independent experiments. 
bioRxiv preprint doi: https://doi.org/10.1101/2021.06.10.444761; this version posted August 10, 2021. The copyright holder for this preprint (which was not certified by peer review) is the author/funder, who has granted bioRxiv a license to display the preprint in perpetuity. It is made available under aCC-BY-NC-ND 4.0 International license.

Table 1. Cellular parameters of the confirmed width-control defficient strains

\begin{tabular}{|c|c|c|c|c|c|c|c|}
\hline Gene & Functional category ${ }^{4}$ & $\delta$ length $^{1}(\%)$ & $P$-value ${ }^{2}$ & $\delta$ width $^{1}(\%)$ & $P$-value ${ }^{2}$ & $\delta \mathrm{GT}^{3}(\mathrm{~min})$ & $P$-value ${ }^{2}$ \\
\hline $\min J$ & cell division & 120.6 & $* * * *$ & -1.0 & $\mathrm{~ns}$ & 5,6 & * \\
\hline$y b z H$ & unknown (putative TR) & 12.9 & $* * * *$ & -9.3 & $* * * *$ & 1,7 & $*$ \\
\hline $\operatorname{rod} z$ & CW homeostasis & 10.7 & $* *$ & 12.5 & $* * * *$ & $-1,1$ & ns \\
\hline yaaA & translation & 4.4 & $* *$ & 9.7 & $* * *$ & $-0,7$ & ns \\
\hline$w t$ & "'-" & 0,0 & $=$ & 0,0 & - & 0,0 & \\
\hline cw/O & CW homeostasis & -5.2 & ns & 13.1 & $* * *$ & 0,3 & $*$ \\
\hline$f t s X$ & CW homeostasis & -8.6 & $* *$ & 10.0 & $* * * *$ & $-0,7$ & ns \\
\hline$f t s E$ & CW homeostasis & -10.9 & $* * * *$ & 9.4 & $* * * *$ & $-0,7$ & ns \\
\hline dacA & CW homeostasis & -11.7 & $* * * *$ & 9.3 & $* * * *$ & $-1,1$ & ns \\
\hline ptsH & central C metabolism & -12.2 & $* * * *$ & -13.3 & $* * * *$ & 17,6 & $*$ \\
\hline pand & central C metabolism & -12.5 & $* * * *$ & -11.4 & $* * * *$ & 11,9 & $*$ \\
\hline rpe & central C metabolism & -13.6 & $* * *$ & 11.0 & $* * * *$ & 12,8 & * \\
\hline pyk & central C metabolism & -21.4 & $* * * *$ & -8.3 & $* * *$ & 36,5 & * \\
\hline guaA & purine metabolism & -36.7 & $* * * *$ & -12.7 & $* * * *$ & 38,1 & * \\
\hline
\end{tabular}

Colors of numbers indicate positively (purple) or negatively (orange) affected value in width or length, or inreased or decreased generation time, compared to the wild type strain

1: difference (in \%) relative to wild type, average of 3 independant pooled replicates
2: statistical significance estimated by nested t-test (Slength $\delta$ width) or Mann-Whitn

P- values are displayed as follow: ${ }^{* * * *}=\mathrm{P}<0.0001 ; * * *=0.0001<\mathrm{P}<0.001 ;{ }^{* *}=0.001<\mathrm{P}<0.01 ;{ }^{*}=0.01<\mathrm{P}<0.05 ; \mathrm{ns}=\mathrm{P}>0.05$

3: difference of generation time (GT) relative to the wild type, averages of 4 independent experiments

4: according to Subtiwiki (Zhu, 2018) 
Juillot et al., Figure 1
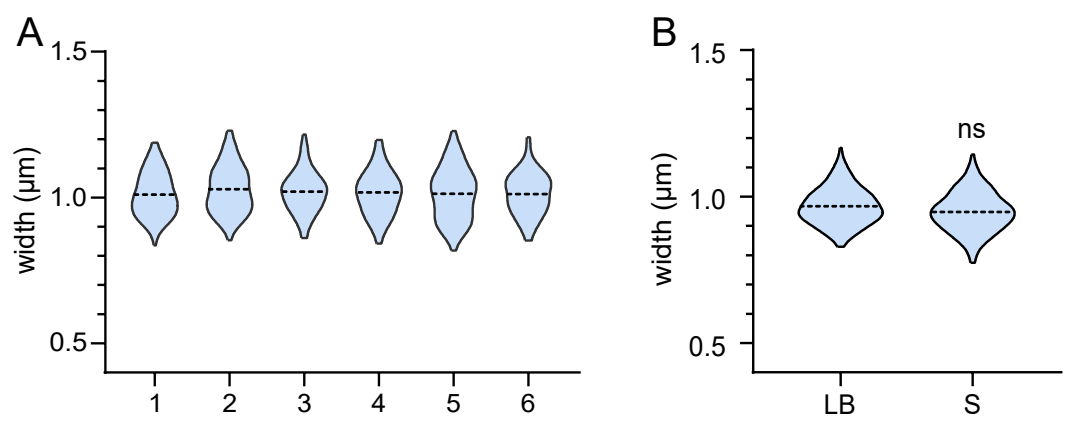

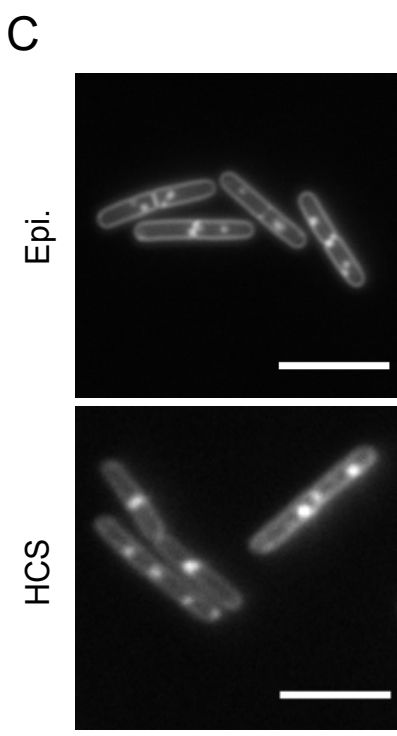

WT
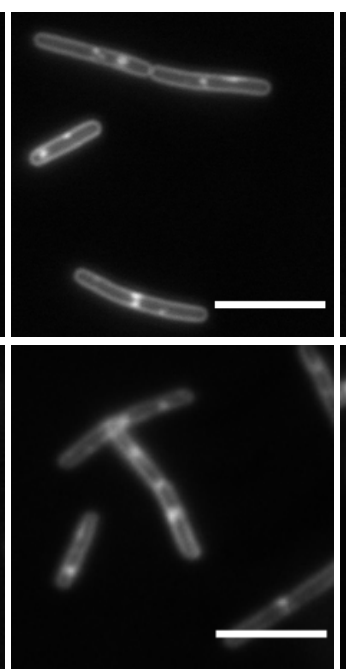

$\Delta$ ponA

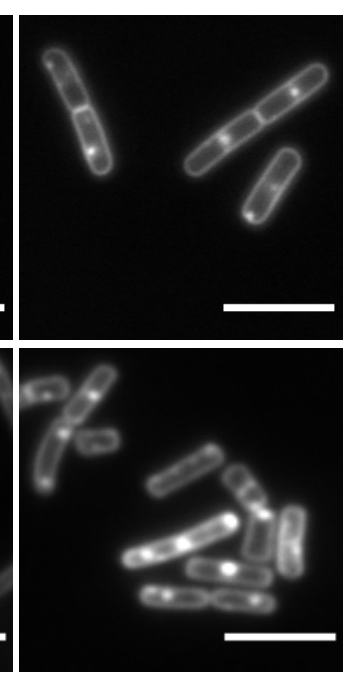

$\Delta m r e B$

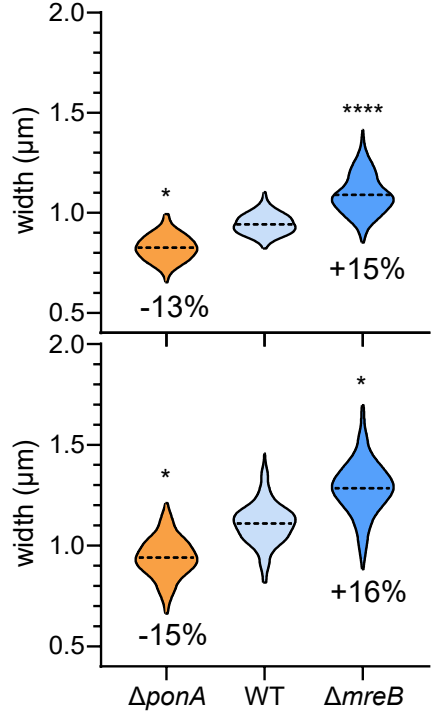

Figure 1. Discrimination of diameter-control deficient $B$. subtilis mutants: a proof of concept.

A. Comparison of cell width distribution of six independent cultures of fixed wild type B. subtilis cells grown in rich (LB) medium, observed on an epifluorescent microscope. One-way ANOVA statistical analysis showed no significant differences between the replicates (Table S3). B. Comparative cell width distributions of fixed wild type $B$. subtilis cells grown in rich (LB) and minimal (S) media (epifluorescent microscope). C. Qualitative (images) and quantitative (distribution of measured cell width) comparisons of data acquired on a wide-field epifluorescence microscope and a confocal HCSm, using the wild type, $\triangle m r e B$ and $\triangle p o n A$ mutant strains of $B$. subtilis. Fluorescent images were acquired on cells grown to mid exponential phase $(0.2<0 D 600 \mathrm{~nm}<0.3)$, fixed and stained with the FM1-43fx membrane dye. Discrete fluorescent foci result from cell fixation. Scale bar, $5 \mu \mathrm{m}$. Width distributions are displayed as violin plots with the broken line indicating the mean. Statistical analyses were performed as described in the method section 'statistical analysis'. When significant, the difference between the means, expressed as a percent, is indicated on the plots. $B$ and $C$ are compilations of at least two independent experiments. 
bioRxiv preprint doi: https://doi.org/10.1101/2021.06.10.444761; this version posted August 10, 2021. The copyright holder for this preprint (which was not certified by peer review) is the author/funder, who has granted bioRxiv a license to display the preprint in perpetuity. It is made available under aCC-BY-NC-ND 4.0 International license.

\section{Juillot et al., Figure 2}

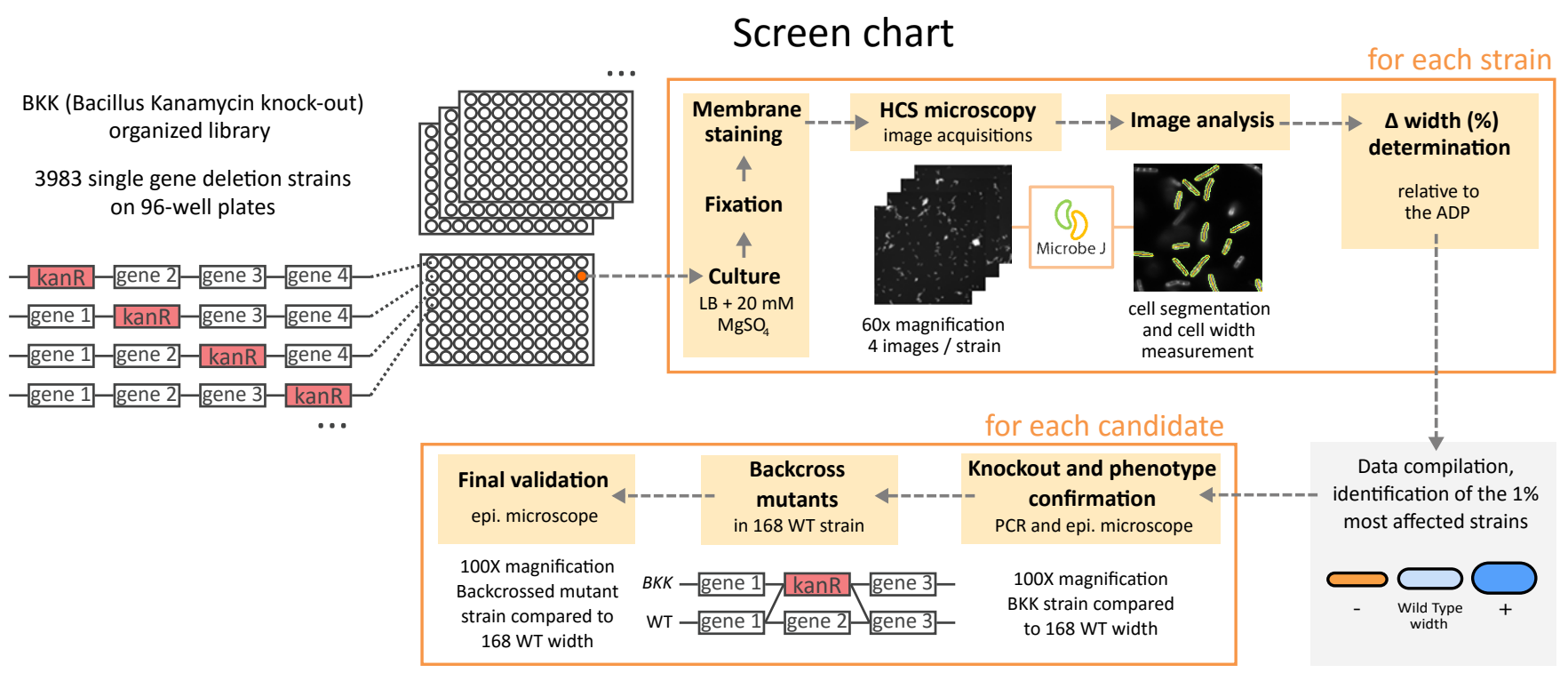

Figure 2. Protocol summary of the screening process.

Screening of the B. subtilis BKK collection arrayed in 96-well plates was based on automated image acquisition using an HCSm. The MicrobeJ plugin of Fiji was used for cell segmentation and width measurements. Average cell diameter of each mutant was compared to the average diameter of all cells on the plate (ADP). Candidates where confirmed by measuring their diameter on images acquired with an epifluorescence microscope, relative to the wild type strain. The selected mutants were then backcrossed into a wild type background before final width determination over triplicate experiments. 
bioRxiv preprint doi: https://doi.org/10.1101/2021.06.10.444761; this version posted August 10, 2021. The copyright holder for this preprint (which was not certified by peer review) is the author/funder, who has granted bioRxiv a license to display the preprint in perpetuity. It is made available under aCC-BY-NC-ND 4.0 International license.

\section{Juillot et al., Figure 3}

A

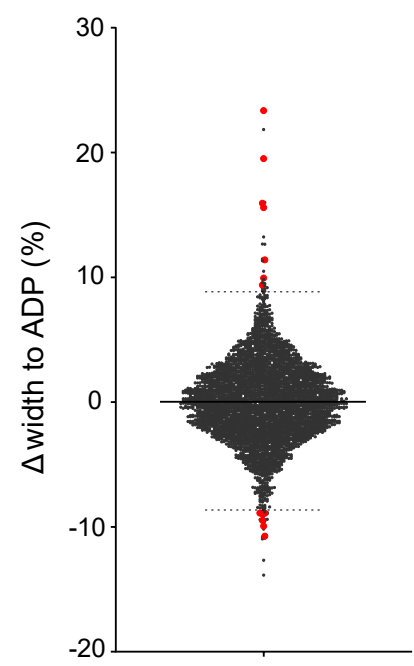

B

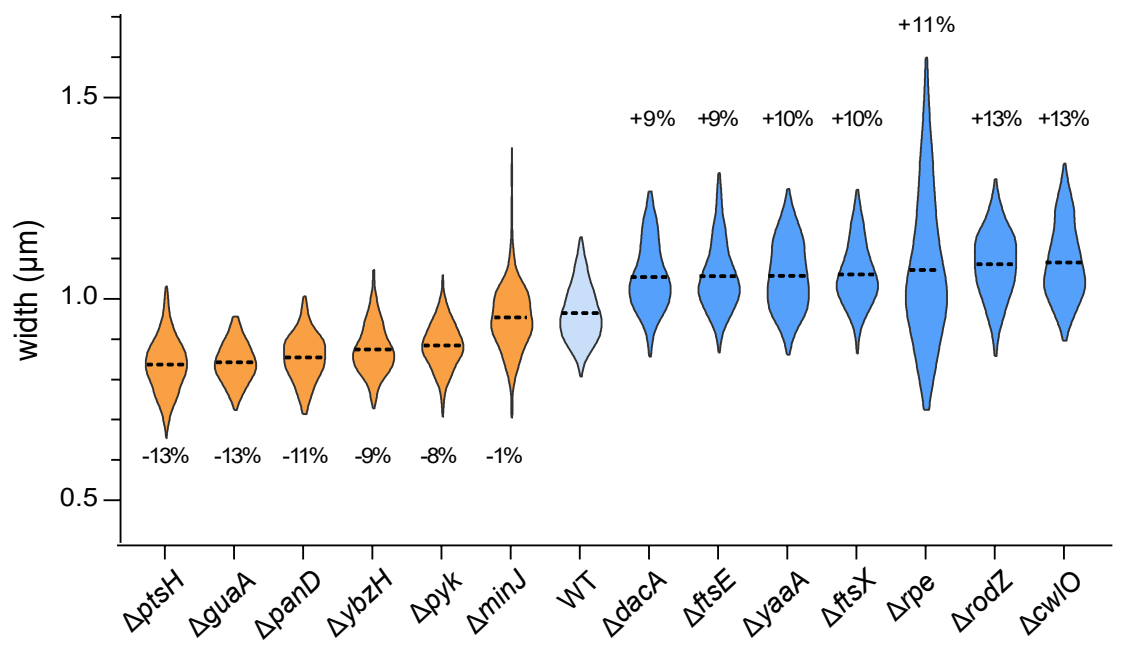

C
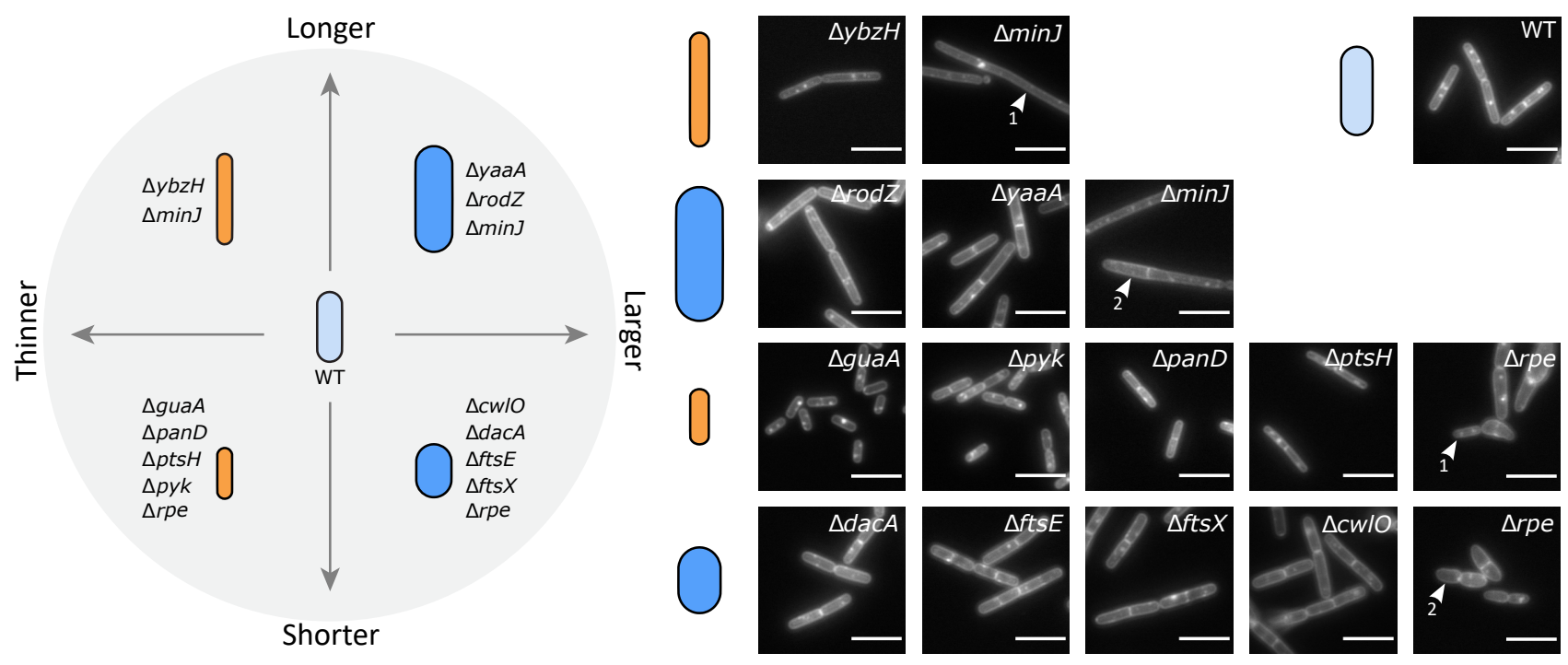

Figure 3 . The screen reveals 13 mutants with a cell width variation $>8 \%$ relative to the wild-type.

A. Width difference ( $\Delta$ width) of each mutant relative to the ADP of its plate. Dotted lines indicate the cut-offs for the $0.5 \%$ largest (top) and thinnest (bottom) mutants. Red dots mark the 13 mutants with confirmed diameter defects after deletion were backcrossed into the wild-type strain. B. Cell width distributions of the 13 selected (backcrossed) mutants. Orange and blue plots correspond to thinner and wider mutants respectively, compared to their parental wild type strain (light blue). Broken line: mean. Data are compilations of three independent experiments. The difference between the means of each mutants and the wild-type is indicated, in \%. Statistical significances between the mutants and the wild type strain width were calculated using nested t-tests (see Table 1 for P-values). All differences were significant except for the mean width of the $\Delta \mathrm{min} J$ mutant. C. Phenotypes of the backcrossed mutants segregate into four classes based on their width and length defects. $\Delta \mathrm{min} J$ and $\Delta r$ re mutants form both thinner (arrowhead, 1 ) and larger (arrowhead, 2) cells. Displayed are images of FM1-43fx membrane-labelled fixed cells. Scale bar, $5 \mu \mathrm{m}$. 


\section{Juillot et al., Figure 4}

A
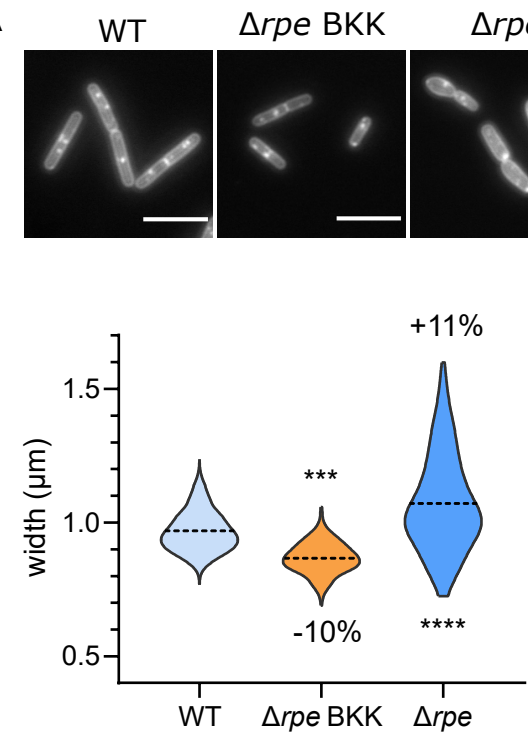

B

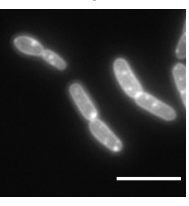

Figure 4. $\Delta \min$ J and $\Delta r p e$ mutants exhibit an uncontrolled diameter phenotype.

A. Images of membrane-labelled strains and corresponding distribution of cell widths for the wild type strain, $\Delta r p e$ from the BKK collection and $\Delta r p e$ backcrossed into 168 wild type background. Broken line: mean. The differences between the means of the mutants and the wild type are indicated, in \%. Data are compilations of two independent experiments and statistical significance between mutants and the wild type strains was calculated with a nested t-test. B. Images of membrane-labelled $\Delta \min J$ mutant, presenting varying width along single cells or chain of cells. This phenotype is observed in approximately $19 \%$ of the population. Percentages indicate the difference of width compared to that of the wild type strain, at the position of the red marks. Scale bars, $5 \mu \mathrm{m}$. 
bioRxiv preprint doi: https://doi.org/10.1101/2021.06.10.444761; this version posted August 10, 2021. The copyright holder for this preprint (which was not certified by peer review) is the author/funder, who has granted bioRxiv a license to display the preprint in perpetuity. It is made available under aCC-BY-NC-ND 4.0 International license.

\section{Juillot et al., Figure 5}
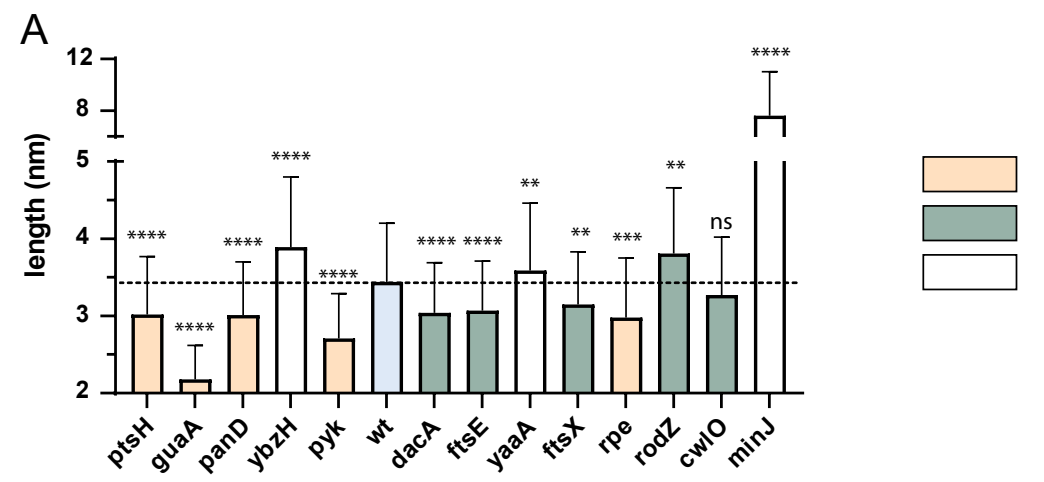

metabolism

CW homeostasis

other functions

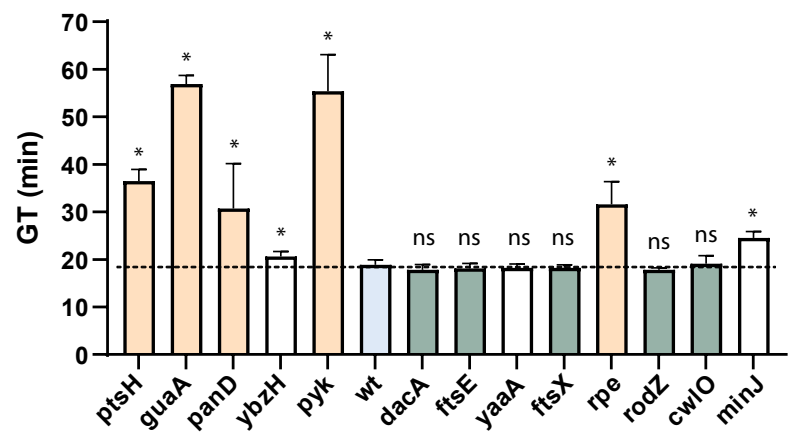

B
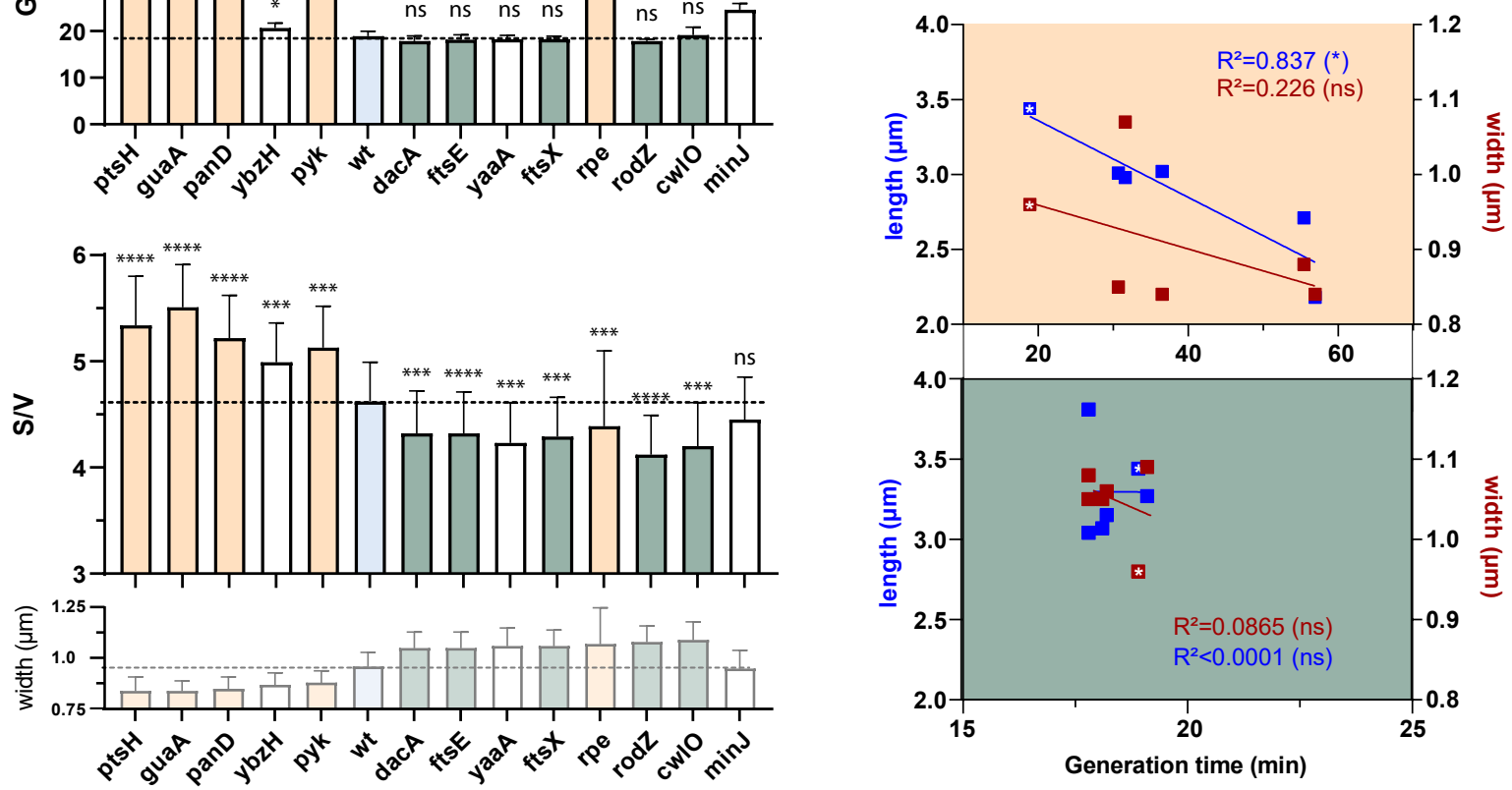

Fig. 5. Relationship between generation time, length, width and surface to volume ratio in the selected mutants.

A. Average length, generation time (GT) and surface to volume ratio (S/V) of cell width deficient (backcrossed) mutants compared to the wild type strain. Width of each strain is recalled (from Fig. 3) for comparison. The dotted line marks the level of the average wild type value. GT are calculated on populations (see the corresponding method section) and are the average of 4 independent experiments. Length and S/V ratio data are calculated per cell and compiled from three independent experiments. Statistical significance were determined as described in the method section 'statistical analysis', and displayed with * for $P$-values. Error bars represent SD. B. Average length and width as a function of the generation time (GT). Upper panel: metabolism-related mutant; lower panel: CW homeostasis-related mutant. $\mathrm{R}^{2}$ of the linear regressions (lines) are indicated on the panels. White stars indicate the wild type values. 